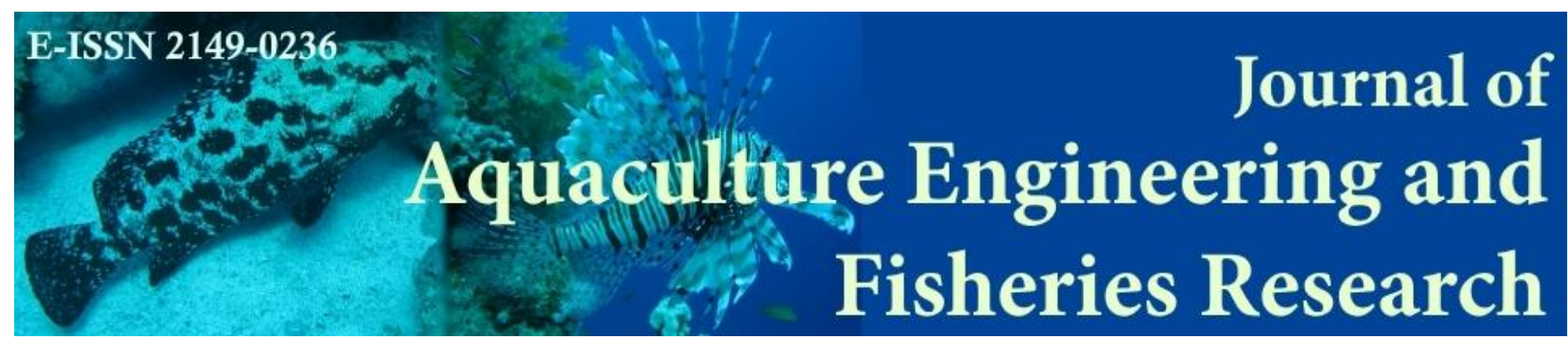

FULL PAPER

TAM MAKALE

\title{
AN OBSERVATION ON INTRACAPSULAR AND POST-EMBRYONIC PHASES OF RIVER NERITE (Theodoxus fluviatilis)
}

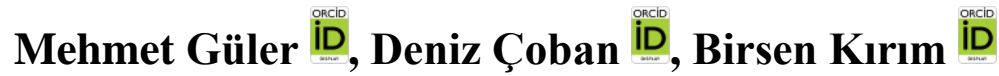

Cite this article as:

Güler, M., Çoban, D., Kırım, B. (2018). An Observation on Intracapsular and Post-Embryonic Phases of River Nerite (Theodoxus fluviatilis). Journal of Aquaculture Engineering and Fisheries Reaserch, 4(1), 46-54. DOI: 10.3153/JAEFR18005

Adnan Menderes University, Faculty of Agriculture, Department of Aquaculture and Fisheries, Aydin, Turkey

Submitted: 14.08 .2017

Accepted: 24.12 .2017

Published online: 27.12 .2017

Correspondence:

Mehmet GÜLER

E-mail: mehmetguler@adu.edu.tr

Journal of Aquaculture Engineering and Fisheries Research

E-ISSN 2149-0236

4(1), 46-54 (2018)

DOI: 10.3153/JAEFR18005

ScientificWebJournals (SWJ) (C)2015-2018

\begin{abstract}
The river nerite (Theodoxus fluviatilis, Linnaeus, 1758) is one of the most common gastropod grazer species in Europe inland and brackish waters. Its feeding activity significantly impacts on periphyton which has a decisive role on the water parameters and the population dynamics. In the present study, reproductive outputs and larval phases of the river nerites were examined via field collected and laboratory cultivated samplings. The length of capsules laid by adults was between 0.7 and $1.1 \mathrm{~mm}$. Viable embryos were detected first on the $33^{\text {rd }}$ day post-spawning. After few development phases embryo reached a ready-to-hatch phase with completely developed foot and pigmented protoconch before hatching. There was never more than one embryo per capsule. The earliest hatching was observed on the $53^{\text {rd }}$ day of spawning. But most of the embryos did not hatch even they were fully developed. The shell length of the hatchlings was about 0.8 and the width was 0.6 $\mathrm{mm}$. It was estimated that the length of a newly hatched crawling juvenile can be about 1/7 of the length of an adult.
\end{abstract}

Keywords: Gastropod, Neritidae, Egg capsule, Embryonic development 


\section{Introduction}

Macrograzers play an important role in both sea and freshwater benthic systems due to their feeding on periphyton (Calow 1975; Underwood, 1981); the change in the amount of periphyton in a system can be decisive on the water parameters and the population dynamics of the organisms (Ramesh et al. 1999; Azim et al. 2004). The river nerite (Theodoxus fluviatilis, Linnaeus, 1758) is one of the most common gastropod grazer species in Europe freshwater and brackish water systems and occurs in Western Asia (Özbek et al. 2004; Ustaoğlu et al. 2003; Şahin and Y1ldırım 2007; Symanowski and Hildebrandt, 2010; Glöer and Pešiæ 2012) and has a significant reduction effect on the periphyton by its feeding activity (Råberg and Kautsky 2007; Peters and Traunspurger 2012).

Due to its versatile, wide distribution, complex habitat (Bunje 2005) and ecological importance, considerably number of study was conducted on $T$. fluviatilis: the aspects about phylogeny and dispersal range (Carlsson 2000; Bunje 2005), growth and population dynamics (Orton and Sibly 1990; Kirkegaard 2006; Graça et al. 2012), morphological features (Zettler et al. 2004; Anistratenko 2005; Glöer and Pešiæ 2015), feeding ecology and grazing (Jacoby 1985; Råberg and Kautsky 2007; Peters and Traunspurger 2012) and tolerance to the environmental stressors (Skoog 1976; Kangas and Skoog 1978; Symanowski and Hildebrandt 2010) were studied before. But surprisingly, little is known about the early life history and very little research were made on the reproductive biology of this species, except several studies (Fretter and Graham 1962; Orton and Sibly 1990) and mostly focused on the productivity or pre-fertilization (Giusti and Selmi 1982; Kirkegaard 2006; Graça et al. 2012). In fact, information about the reproduction biology of family Neritidae is limited in general. Generally it is difficult to make observation on the intracapsular phases of nerites due to opaque structure of the capsules and therefore information on the early phases of these species is limited.

Larval phases determine the postlarval characteristics (Rivest 1983; Krug 1998; Collin et al. 2007) and dispersal potential of the juveniles or/and adults (Pechenik 1999). In the present study, larval phases of the river nerites were observed to prepare some descriptions on their early life phases. And reproductive outputs of this species were examined via field collected and laboratory cultivated samplings to obtain knowledge that can be used in modelling, stock management and cultivation studies.

\section{Materials and Methods}

All of the specimens (nerites and egg capsules) were collected gently with hand from Yuvarlakçay stream (Köyceğiz, Muğla, Turkey) between 2013 November and 2014 July. The initial collected specimens were used in the pre-experiments to find suitable experimental setup. Generally nerites were found under rocks and rarely attached to roots. Egg capsules were collected with the rocks that they already attached, without detachment. All of the material were transferred to the laboratories alive at the same day in water filled containers with portable aerator and -when necessary ice addition to prevent high water temperatures (above $20 \mathrm{C}^{\circ}$ ). The species identification was made morphologically according to Zettler et al. (2004) and Glöer and Pešiæ (2015), with extracting and examining of the radulae and operculum of the specimens under stereo microscope.

Nerites were grouped and taken to the $40 \mathrm{~L}$ stock aquariums, equipped with aeration, heaters and filters. Observations were maintained in six all glass experiment aquariums (filled with $15 \mathrm{~L}$ water) with small rocks. While 5 of the aquariums contained nerites, one aquarium contains only egg capsules (from the field) with the rocks they already attached. Because the nerites were extremely sensitive to unsteady conditions (according to pre-observations), every two aquariums were grouped and connected to a larger aquarium (40 L) which equipped with aeration and filters (nerites had no chance to escape from experiment aquarium to additional aquarium). Therefore larger volume (about $70 \mathrm{~L}$ ) and miniature recirculating systems were set up in order to provide more stable water conditions (Figure 1). Additionally, 15 glass jars $(800 \mathrm{ml})$ were placed in a large aquarium (filled with water at the same level as the water in the jars) to record the number of capsule per female; one randomly chosen nerite was placed in each jar. The water temperature was kept between $18-20^{\circ} \mathrm{C}$ to maintain reproduction activities and embryonic development (Skoog 1976). The laboratories were air-conditioned but ice addition with the plastic bags to aquariums was made when necessary. Initial measurements of the dissolved $\mathrm{O}_{2}$ were made by portable multi-parameter meter (WTW Multi 3420); DO in aquariums never dropped below $90 \%$ saturation, during the experimental period. 


\section{Journal of Aquaculture Engineering and Fisheries Research, 4(1), 46-54 (2018)}

\section{Journal abbreviation: J Aquacult Eng Fish Res}

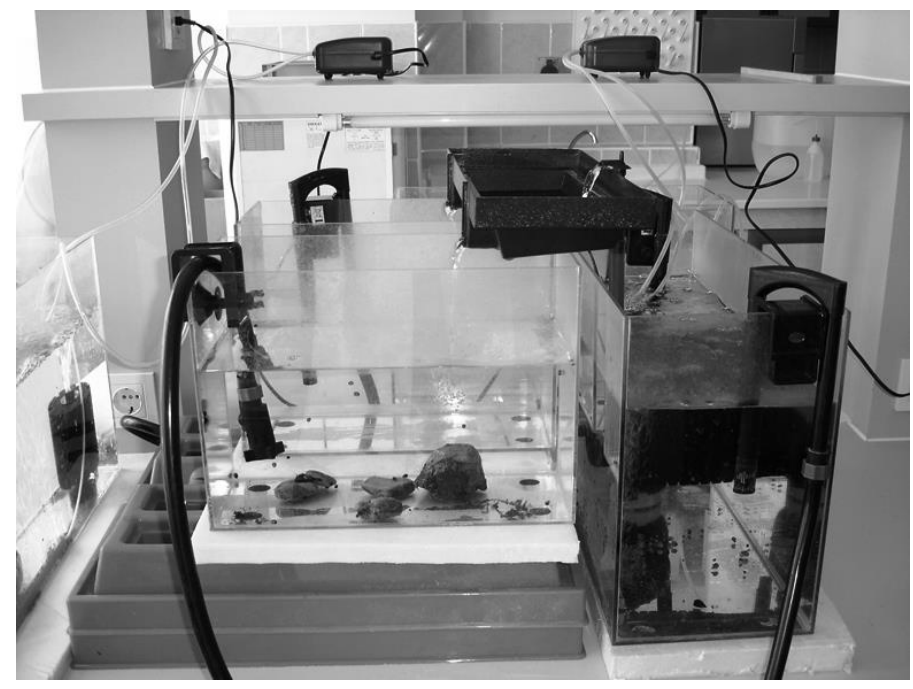

Figure 1. Photograph from a pre-experiment which has a similar setup.

Nerites were measured with caliper prior to the experiments and placed into the experiment aquariums. Experimental setups monitored continuously. Biometric measurements of the collected (from the field) and spawned (at the laboratory) capsules were made with an image analyses software (Imagefocus3) using high resolution digital photographs taken by a microscope mounted digital camera (Cmex 5000 digital camera, Novex RZ stereo microscope) according to Barroso and Matthews-Cascon (2009). Because of their opaque structure, capsules opened with a scalpel in order to examine intracapsular inclusions. Intracapsular examinations were made with the same microscope, camera and software setup. After hatching, the characteristics of the newly hatched juveniles were examined with the same setup again.

Regressions of the shell length (SL, mm) against shell width (SW, mm) of the nerites ( $\mathrm{n}=63)$, length $(\mathrm{CL}, \mathrm{mm})$ against width $(\mathrm{CW}, \mathrm{mm})$ of the egg capsules $(\mathrm{n}=79)$ and shell length (SL, mm) against shell width (SW, $\mathrm{mm}$ ) of the hatchlings/ready to hatch individuals $(n=17)$ were made to describe the general morphology. Given the size ranges of nerites, capsules and hatchlings, results were logarithm $(\log 10)$ transformed prior to analyses to remove any potential effects due to allometry (Mascaro et al., 2014). But linear regression of the actual sizes was also made to find relationship formula. Changes in the sizes of the capsules during experiments were tested with one way ANOVA.

\section{Results and Discussion}

The shell length and the width relation of the nerites were found to be related (Figure 2). Mating was observed rarely but continued until the end of the experiments (Figure 3a). Egg laying was first observed in the middle of May at $18 \mathrm{C}^{\circ}$ water temperature. The capsules were attached firmly to the stones that placed into the aquarium. At the field, capsules were found under rocks and rarely on tree roots. Capsules, both in the natural environment and in the laboratory, were circular-elliptical, rigid and translucent-opaque (Figure 3b, Figure $5 \mathrm{c}$ ); at the beginning they were white, and then darkened to dark cream-light brown. The last capsule laying event in laboratory was recorded at the end of July $\left(18 \mathrm{C}^{\circ}\right)$. The mean capsule length was $1002 \pm 83 \mu \mathrm{m}( \pm \mathrm{SD}$, min $=710$, $\max =1138)$ and the mean width was $832 \mathrm{~L} \pm 84 \mu \mathrm{m}(623-977$ $\mu \mathrm{m})$ and following equation was found between length (L) and the width (W) of the capsules: $W=0.738+92.672$ $\left(\mathrm{R}^{2}=0.53\right)$ (Figure 4$)$. Sizes of the capsules did not change during the time between laying and hatching (ANOVA, $\mathrm{df}=3, \mathrm{~F}=1.03, \mathrm{p}=0.39$ ). Capsules were filled with a transparent and viscose liquid and eggs.

Viable embryos were detected first on the $33^{\text {rd }}$ day postspawning with eyes (Figure 5a). At this phase, embryonic shell (protoconch) started to form and its length was measured $275 \mu \mathrm{m}$ and the width was $222 \mu \mathrm{m}$. After this phase a rapid development was observed; the next week larvae reached $310 \pm 29 \mu \mathrm{m}(250-360)$ shell length and $247 \pm 30 \mu \mathrm{m}$ (190-290) shell width (Figure 5b). After few development phases embryo reached a ready to hatch phase with completely developed foot and pigmented protoconch before the exit (Figure 5c). There was never more than one embryo per capsule. The earliest hatching was observed on the $53^{\text {rd }}$ day of laying (between 53-65 days). But most of the embryos did not hatch even they were fully developed (having the same characteristics with the hatched individuals). The shell length of the hatchlings (Figure $5 \mathrm{~d}$ ) was $785 \pm 35 \mu \mathrm{m}(\mathrm{n}=5$; $755-839)$, and the width was $624 \pm 42 \mu \mathrm{m}$ (566-670). With pooling all of the data from the hatchlings and ready to hatch (but not naturally hatched) individuals, this equation was found between shell length (SL) and the width (W) of the hatchlings: $S L=0.888 \mathrm{~W}+228.91\left(\mathrm{R}^{2}=0.71\right)$, (Figure 6). 


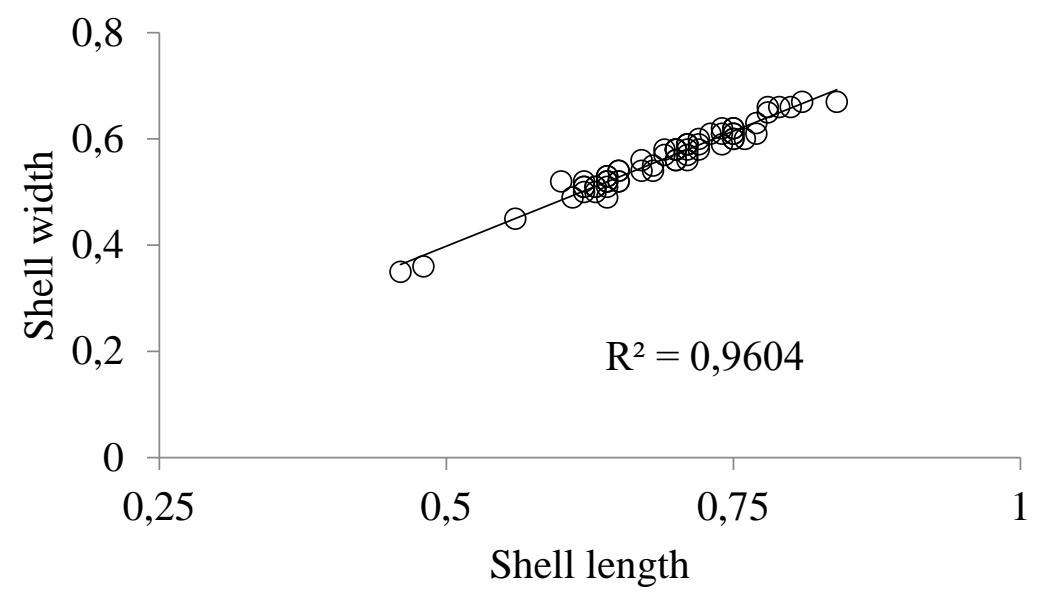

Figure 2. Regressions of shell length against shell width of the nerites within the 2.9-6.8 mm length and $2.22-4.66 \mathrm{~mm}$ width ranges $(n=63)$. Data are logarithm $(\log 10)$ transformed.
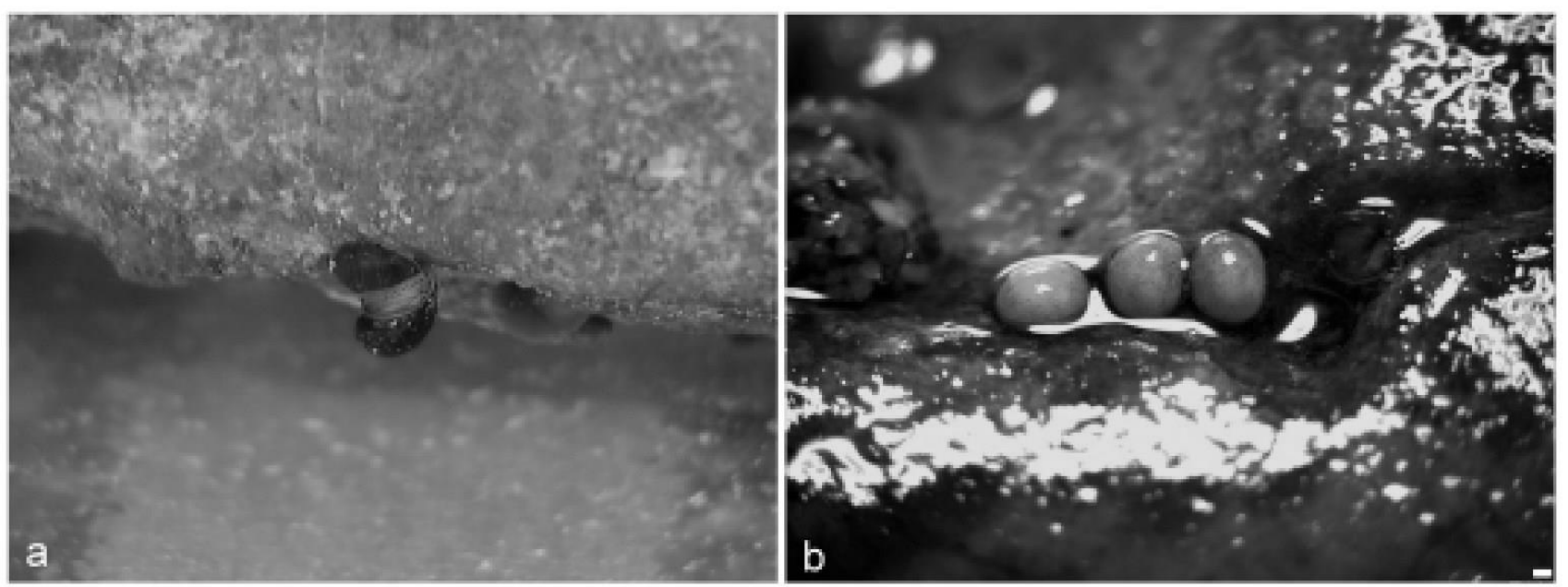

Figure 3. (a) Mating, (b) egg capsules laid by the same female on a stone in the experiment aquarium (Scale bar=200 $\mathrm{m} \mu)$.

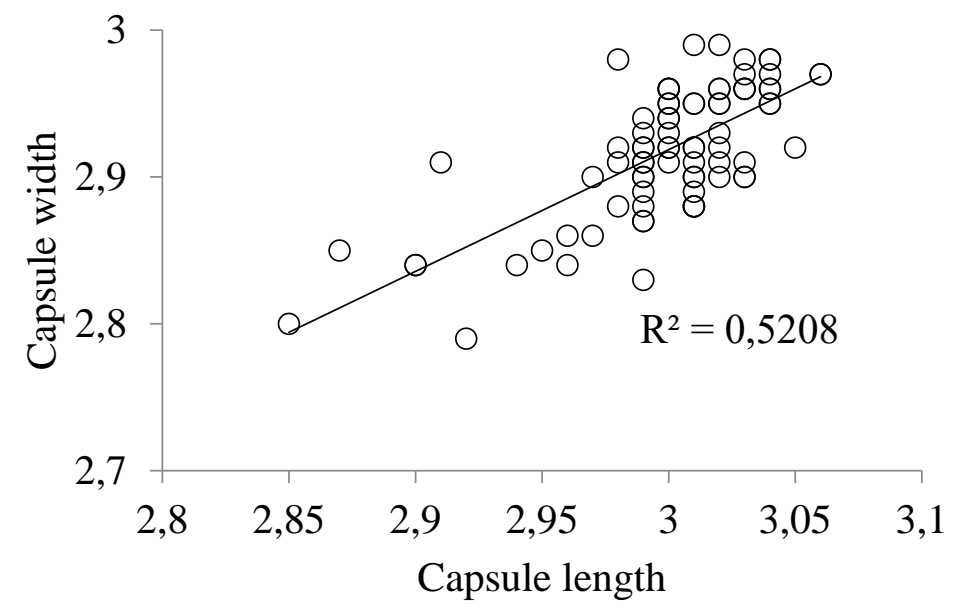

Figure 4. Regressions of capsule length against capsule width within the 710-1138 capsule length range and 623-977 $\mu \mathrm{m}$ capsule width range $(n=79)$. Data are logarithm transformed. 


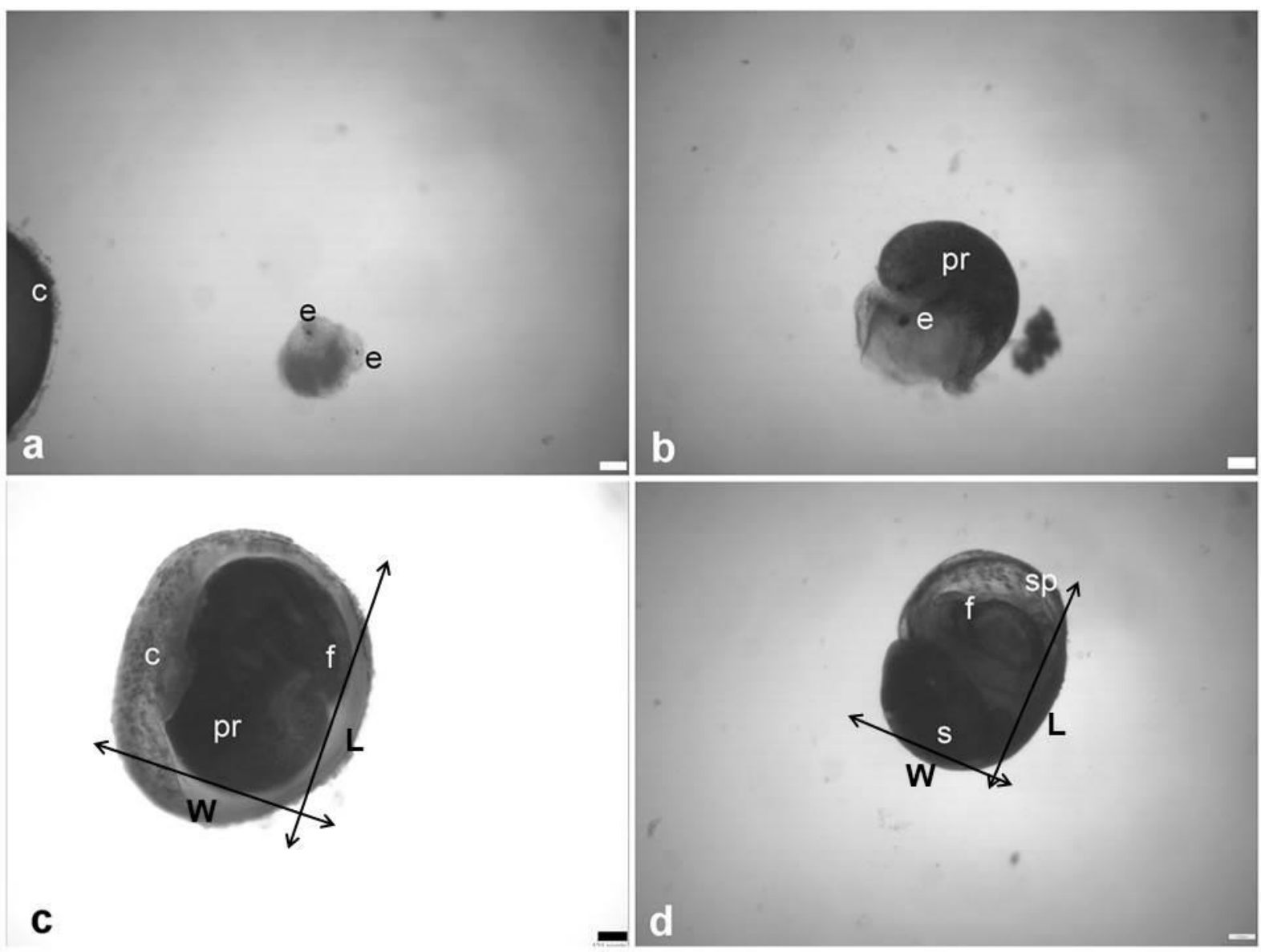

Figure 5. (a) Viable embryo, at the first observation; (b) pre-hatching larvae; (c) fully developed and ready to hatch larva in the capsule; (d) crawling juvenile nerite. c, capsule; e, eye; pr, protoconch; f, foot; s, shell; sp, shell pigmentations; L, length; W, width. Scale bars: $100 \mu \mathrm{m}$.

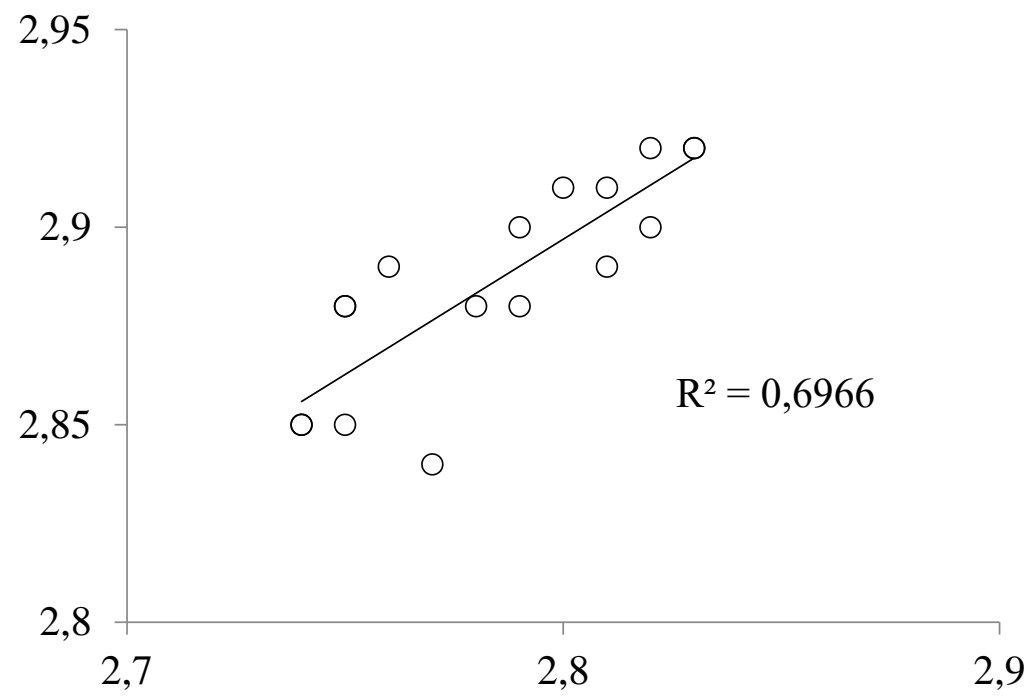

Figure 6. Regressions of shell length (693-839 $\mu \mathrm{m}$ range) against shell width (546-681 $\mu \mathrm{m}$ range) of the hatchlings and ready to hatch individuals. Data are logarithm transformed. 


\title{
Journal of Aquaculture Engineering and Fisheries Research, 4(1), 46-54 (2018)
}

\author{
Journal abbreviation: J Aquacult Eng Fish Res
}

All of the members of family Neritidae lay their eggs in egg capsules but different species have different development modes. For example brackish water nerites Clithon spinosus, Neritina latissima, have generally short term planktotrophic larval stages (Ford 1979; Resh et al. 1992; MatthewsCascon and Martins 1999). Marine species like Nerita atramentosa, $N$. plicata spend much longer period (up to 6 months) at the plankton as planktotrophic veligers (Underwood 1975; Kano 2006). The development mode Theodoxus is intracapsular metamorphosis or direct development, all of the larval phases are completed in the egg capsules and crawling hatchlings are fully developed before the hatching (Fretter and Graham 1962; Orton and Sibly 1990; Bunje 2005). In the present study, all of the observed larvae completed their metamorphosis in the capsules, and no escape was detected until the end of larval period and becoming miniatures of the adults. This result is compatible with the earlier studies (Kirkegaard 2006) on T. fluviatilis. Velar structures in planktotrophic species are well-developed that suitable for swimming and feeding (Moran 1997) and also can be well-developed in non-planktotrophic species and can be used for intracapsular feeding (Güler and Lök, 2014). At the present study velar structures were not clearly observed but movement of the early embryos might have been provided by an under developed velum. But Collin (2004) showed that the possibility of the losing all velar characters in two direct developer (nurse eggs, single embryo per capsule) Crepidula (Gastropoda, Calyptraeidae) species and this situation can be valid for T. fluviatilis too.

T. fluviatilis shows oophagic development with nurse eggs. At the spawning, egg capsule contains 50 to 200 eggs, only one of them develops and the others serve as nutrition for the embryo (Bondesen 1940; Carlsson 2000). According to the results of the study, each egg capsule contains only one live embryo, so that only one live non-planktonic juvenile is hatchling from each capsule. It is normal that non-planktotrophic or direct developer gastropods produce fewer hatchlings per capsule than species that spend their early life at the plankton (Pechenik 1979; Collin 2003). However single embryo production is rare and already fewer hatchlings per capsule is a disadvantage for continuity of the generation (Pechenik 1979). At this point the number of capsules laid by one female comes forward as an important reproductive success parameter. The number of capsule per female was found quite different at the present study compared to the reports of Kirkegaard (2006) from a field study. Kirkegaard (2006) estimated that one female can lay approximately 40 capsules per spawning season at the field, but not dependent on a direct observation. According to an earlier study, one female can lay about 10 capsules per season (Bondesen 1940). At the present study one female laid maximum four capsules; as far as can be observed. But the differences simply can be associated with the differences of laboratory and field conditions or different temperatures that could induce different metabolic responses (Cumplido et al. 2011) or any stressor/stressors at the laboratory conditions. Moreover sizes of the capsules were slightly different from the findings of Kirkegaard (2006). Kirkegaard (2006) reported between 0.9 and $1.1 \mathrm{~mm}$ for intact capsules and 0.5-0.8 $\mathrm{mm}$ for empty capsules, and according to Neumann (1959) empty capsules are sterile. We recorded between $\sim 0.7$ and $1.1 \mathrm{~mm}$ capsule size and none of them are empty or sterile (both laboratory and field samples). The sizes of the capsules did not change at the larval period, this observation may support the explanation of Neumann (1959) that the empty capsules are sterile. If the empty capsules were filled at the beginning they must get larger by the time because sizes of the filled capsules were found at the common sizes every time (more than $0.9 \mathrm{~mm}$ by Kirkegaard (2006) and more than $0.7 \mathrm{~mm}$ by the present study). We found that the capsule sizes did not change at the larval period. So the small capsules might be sterile and might be empty from the spawning because they do not expand.

During the study only 5 hatching event was observed, although there are many more intact capsules available at the experimental setup. The mechanism of hatching or larval release from the egg capsule is still unknown for many gastropod species (Pechenik 1986; Tan and Lee 2009; Przeslawski 2011) including $T$. fluviatilis (to authors' knowledge). For some marine species a chemical mechanism was described. For example some Tritia species (family Nassariidae) and Ocenebra erinaceous (Muricidae) hatch or escape from the egg capsules with removal of the plug of the capsules after an intracapsular chemical process (Pechenik 1986; Hawkins and Hutchinson 1988). For nerites, environmental factors at the natural habitat like currents or waves can effect to the hatching mechanism (Przeslawski 2011). For example Lesoway and Page (2008) reported that the embryos of Nerita atramentosa (Neritidae) do not hatch at the laboratory conditions unless the egg capsules opened artificially. Przeslawski (2011) suggested the effect of wave action to explain this situation as well as her personal observations on the emerging time from capsule. Generally $T$. fluviatilis is morphologically adapted to live in streams with swift currents and at the wave zone of lakes (Kirkegaard 2006). Considering the -relatively stationary environment of the experimental setups, this suggestion may be explain our 


\section{Journal of Aquaculture Engineering and Fisheries Research, 4(1), 46-54 (2018)}

Journal abbreviation: J Aquacult Eng Fish Res

findings. Moreover other environmental factors like temperature can regulate or delay the realising time of larvae (or post larva) as adaptation to increase chances of survival in changing environmental conditions (Barroso and MatthewsCascon 2009; Przeslawski 2011).

The mean hatching size was recorded about $0.8 \mathrm{~mm}$ at the present study. The sexual maturity size of $T$. fluviatilis is 5.5 $\mathrm{mm}$ in shell length (Skoog 1971) so the length of a newly hatched juvenile can be calculated as about $1 / 7$ of an adults'. The size of these hatchlings can be considered normal for a species with direct development but hatchling size/adult size ratio is remarkable (Collin 2003). Big hatchlings are generally more resistant to environmental conditions (Pechenik 1979; Etter 1989) and less likely to be consumed by predators (Gosselin 1997). And it seems that T. fluviatilis tries to produce the largest hatchlings possible. Similar situation were reported before for two Crepidula species with the similar embryonic development characteristics like single embryo per capsule, nurse eggs, very big hatchlings (Collin, 2004).

\section{Conclusion}

In summary, T. fluviatilis can be described as a species with no planktonic-planktotrophic larval stage and thus probably has a limited dispersal potential. Moreover, only single embryo production per capsule can be considered as an additional disadvantage in terms of continuity of the generation. In contrast, egg capsules of the river nerites have a solid-hard structure that can guarantee a successful larval stage without any disruption. As we seen in our study, the hatchlings of $T$. fluviatilis are fully developed, quite big (when considering the size of adults) and are miniature of the adults. Despite their disadvantages, it is commonly assumed that the species complete their development in this way are more resistant to dangers of early life than planktotrophicplanktonic relatives, and limited dispersal capacity may have some advantages like post larval development in favourable natal habitat (Pechenik 1999; Krug 1998).

\section{Acknowledges}

This study was supported by Adnan Menderes University Research Projects (BAP project no: ZRF-13007). Authors thank Dr. Michael Zettler for his help in identification of the species, Hafize Sert for help in biometric measurements, K1lıç Deniz Ürünleri A.Ş. for the equipment and İlmiye Güler for her work in the field. The authors are also grateful to the anonymous referees that helped to improve the manuscript.

\section{References}

Anistratenko, V.V. (2005). Lectotypes for Tricolia pullus, Gibbula divaricata and Theodoxus fluviatilis (Mollusca, Gastropoda) revisited. Vestnik zoologii, 39(6), 310.

Azim, M.E., Wahab, M.A., Biswas, P.K., Asaeda, T., Fujino, T., Verdegem, M.C.J. (2004). The effect of periphyton substrate density on production in freshwater polyculture ponds. Aquaculture, 232(1-4), 441-453.

Barroso, C.X., Matthews-Cascon, H. (2009). Spawning and intra-capsular development of Neritina zebra (bruguière, 1792) (mollusca: Gastropoda: Neritidae) under laboratory conditions. Invertebrate Reproduction and Development, 53(3), 137-143.

Bondesen, P. (1940). Preliminary investigations into the development of Neritina fluviatilis L. in Brackish and Fresh Water. Videnskabelige Meddelelser fra Dansk Naturhistorisk Forening, 104, 157-220.

Bunje, P.M.E. (2005). Pan-european phylogeography of the aquatic snail theodoxus fluviatilis (gastropoda: Neritidae). Molecular Ecology, 14(14), 4323-4340.

Calow, P. (1975). The feeding strategies of two freshwater gastropods, Ancylus fluviatilis müll. and Planorbis contortus linn. (pulmonata), in terms of ingestion rates and absorption efficiencies. Oecologia, 20(1), 33-49.

Carlsson, R. (2000). The distribution of the gastropods Theodoxus fluviatilis (L.) and potamopyrgus antipodarum (gray) in lakes on the åland islands, southwestern Finland. Boreal Environment Research, 5(3), 187-195.

Collin, R. (2003). Worldwide patterns in mode of development in calyptraeid gastropods. Marine Ecology Progress Series, 247, 103-122.

Collin, R. (2004). Phylogenetic Effects, the Loss of Complex Characters, and the Evolution of Development In Calyptraeid Gastropods. Evolution, 58(7), 1488-1502.

Collin, R., Chaparro, O.R., Winkler, F., Veliz, D. (2007). Molecular phylogenetic and embryological evidence that feeding larvae have been reacquired in a marine gastropod. Biological Bulletin, 212, 83-92. 


\section{Journal of Aquaculture Engineering and Fisheries Research, 4(1), 46-54 (2018)}

Journal abbreviation: J Aquacult Eng Fish Res

Cumplido, M., Pappalardo, P., Fernandez, M., Averbuj, A., Bigatti, G. (2011). Embryonic development, feeding and intracapsular oxygen availability in Trophon geversianus (Gastropoda: Muricidae). Journal of Molluscan Studies, 77, 429-436.

Etter, R. J. (1989). Life history variation in the intertidal snail Nucella lapillus across a wave-exposure gradient. Ecology, 70, 1857-1876.

Ford, J.I. (1979). Biology of a Hawaiian fluvial gastropod Neritina granosa (Prosobranchia: Neritidae). M.Sc. dissertation, University of Hawaii, Hawaii, USA.

Fretter, V. \& Graham, A. (1962). British Prosobranch Molluscs: Their Functional Anatomy and Ecology. Ray Society, London. ISBN 0903874121

Giusti, F., Selmi, M. G. (1982). The morphological peculiarities of the typical spermatozoa of theodoxus fluviatilis (L.) (neritoidea) and their implications for motility. Journal of Ultrasructure Research, 78(2), 166-177.

Glöer, P., Pešiæ, V. (2012). The freshwater snails (Gastropoda) of Iran, with descriptions of two new genera and eight new species. ZooKeys, 219, 11-61.

Glöer, P., Pešiæ, V. (2015). The morphological plasticity of Theodoxus fluviatilis (Linnaeus, 1758) (mollusca: Gastropoda: Neritidae). Ecologica Montenegrina, 2(2), 8892.

Gosselin, L.A. (1997). An ecological transition during juvenile life in a marine snail. Marine Ecology Progress Series, 157, 185-194.

Graça, M.A.S., Serra S.R.Q., Fereria V. (2012). A stable temperature may favour continuous reproduction by Theodoxus fluviatilis and explain its high densities in some karstic springs. Limnetica, 31(1), 129-140.

Güler, M., Lök, A. (2014). Embryonic development and intracapsular feeding in Hexaplex trunculus (Gastropoda: Muricidae). Marine Ecology 35(2), 193-203.

Hawkins, L.E., Hutchinson, S. (1988). Egg capsule structure and hatching mechanism of Ocenebra erinacea (L.) (Prosobranchia: Muricidae). Journal of Experimental Marine Biology and Ecology, 119(3), 269-283.
Jacoby, J.M. (1985). Grazing effects on periphyton by theodoxus fluviatilis (gastropoda) in a lowland stream. Journal of Freshwater Ecology, 3(2), 265-274.

Kangas, P., Skoog, G. (1978). Salinity tolerance of theodoxus fluviatilis (mollusca, gastropoda) from freshwater and from different salinity regimes in the Baltic Sea. Estuarine and Coastal Marine Science, 6(4), 409-416.

Kano, Y. (2006). Usefulness of the opercular nucleus for inferring early development in neritomorph gastropods. Journal of Morphology, 267, 1120-1136.

Kirkegaard, J. (2006). Life history, growth and production of Theodoxus fluviatilis in Lake Esrom, Denmark. Limnologica, 36 (1), 26-41.

Krug, P.J. (1998). Poecilogony in an estuarine opisthobranch: planktotrophy, lecithotrophy, and mixed clutches in a population of the ascoglossan Alderia modesta. Marine Biology, 132, 483-494.

Lesoway, M.P., Page, L.R. (2008). Growth and differentiation during delayed metamorphosis of feeding gastropod larvae: Signatures of ancestry and innovation. $\mathrm{Ma}$ rine Biology, 153, 723-734.

Mascaro, J., Litton, C.M., Hughes, R.F., Uowolo, A., Schnitzer, S. A. (2014). Is logarithmic transformation necessary in allometry? Ten, one-hundred, one-thousandtimes yes. Biological Journal of the Linnean Society, 111: 230-233.

Matthews-Cascon, H. \& Martins, I.X. (1999). Notes on the reproduction of Neritina virginea (Linnaeus, 1758) in northeast Brazil (Mollusca: Gastropoda: Neritidae). Arquivos de Ciências do Mar, 32, 129-132.

Moran A.L. (1997). Size, form, and function in the early life histories of the gastropod genera Nucella and Littorina. Ph.D. dissertation, University of Oregon, Eugene.

Neumann, D. (1959). Morphologische und experimentelle untersuchungen über die variabilität der farbmuster auf der schale von Theodoxus fluviatilis L. Zeitschrift Für Morphologie Und Ökologie Der Tiere, 48(4), 349-411. 


\section{Journal of Aquaculture Engineering and Fisheries Research, 4(1), 46-54 (2018)}

Journal abbreviation: J Aquacult Eng Fish Res

Orton, R.A., Sibly, R.M. (1990). Egg size and growth rate in Theodoxus fluviatilis (L.). Functional Ecology, 4, 91-94.

Özbek, M., Ustaoğlu M.R., Balık, S., Sarı, H. (2004). Batı Karadeniz Bölgesi'ndeki bazı göllerin Mollusca faunası. Ulusal Malakoloji Kongresi, İzmir, 163-170s.

Pechenik, J.A. (1979). Role of encapsulation in invertebrate life histories. American Naturalist, 114, 859-870.

Pechenik J.A. (1986). The encapsulation of eggs and embryos by molluscs: an overview. American Malacological Bulletin, 4(2), 165-172.

Pechenik, J. (1999). On the advantages and disadvantages of larval stages in benthic marine invertebrate life cycles. Marine Ecology Progress Series. 177, 269-297.

Peters, L., Traunspurger, W. (2012). Temporal patterns in macrograzer effects on epilithic algae and meiofauna: A comparative approach to test for single species and whole grazer community effects. Aquatic Sciences, 74(2), 229-240.

Przeslawski, R. (2011). "Notes on the Egg Capsule and Variable Embryonic Development of Nerita Melanotragus (Gastropoda: Neritidae)." Molluscan Research, 31(3), 152-158.

Råberg, S., Kautsky, L. (2007). Consumers affect prey biomass and diversity through resource partitioning. Ecology, 88, 2468-2473.

Ramesh, M.R., Shankar, K.M., Mohan, C.V., Varghese, T.J. (1999). Comparison of three plant substrates for enhancing carp growth through bacterial biofilm. Aquaculture Engineering, 19, 119-131.

Resh, V.H., Barnes, J.R., Benis-Steger, B., Craig, D.A. (1992). Life history features of some macroinvertebrates in a French Polynesian stream. Studies on Neotropical Fauna and Environment, 27, 145-153.

Rivest B.R. (1983). Development and the influence of nurse egg allotment on hatching size in Searlesia dira (Reeve, 1846) (Prosobranchia: Buccinidae). Journal of Experimental Marine Biology and Ecology, 69, 217241.
Skoog, G. (1971). Variations in the distribution of Theodoxus fluviatilis on stony localities in the northern Baltic proper. Thalassia Jugoslavica, 7, 363-372.

Skoog, G. (1976). Effects of Acclimatization and Physiological State on the Tolerance to High Temperatures and Reactions to Desiccation of Theodoxus fluviatilis and Lymnea peregra. Oikos, 27(1), 50-56.

Symanowski, F., Hildebrandt, J. (2010). Differences in osmotolerance in freshwater and brackish water populations of Theodoxus fluviatilis (Gastropoda: Neritidae) are associated with differential protein expression. $\mathrm{JO}_{\mathrm{O}}$ urnal of Comparative Physiology, 180(3), 337-346.

Şahin, S.K., Yıldırım, M.Z. (2007). The Mollusk Fauna of Lake Sapanca (Turkey: Marmara) and Some PhysicoChemical Parameters of Their Abundance. Turkish Journal of Zoology, 31, 47-52.

Tan, K.S., Lee, S.S.C. (2009). Neritid egg capsules: are they all that different? Steenstrupia, 30, 115-125.

Underwood, A.J. (1975). Comparative studies on the biology of Nerita atramentosa Reeve, Bembicium nanum (Lamarck) and Cellana tramoserica (Sowerby) (Gastropods: Prosobranchia) in S.E. Australia. Journal of Experimental Marine Biology and Ecology, 18, 153172.

Underwood, A.J. (1981). Structure of a rocky intertidal community in new south wales: Patterns of vertical distribution and seasonal changes. Journal of Experimental Marine Biology and Ecology, 51(1), 57-85.

Ustaoğlu, M.R., Balık, S., Özbek, M. (2003). Yuvarlakçay'ın (Köyceğiz-Muğla) Mollusca Faunası. Ege Üniversitesi Su Ürünleri Dergisi, 20(3-4), 433-438.

Zettler, M., Frankowski, J., Bochert, R \& Rohner, M. (2004). Morphological and ecological features of Theodoxus fluviatilis (Linnaeus, 1758) from Baltic brackish water and German freshwater populations. Journal of Conchology, 38 (3), 305-316. 